Article Type: Research Paper

\title{
The Determinants of the Value of Mahr in Muslim Societies: Evidence from the Indonesian Family Life Surveys
}

\author{
Dian Friantoro ${ }^{1}$ and Akhmad Akbar Susamto ${ }^{1,2}$
}

\section{OPEN}

\section{AFFILIATION:}

1 Graduate School, Universitas Gadjah Mada, Special Region of Yogyakarta, Indonesia

2 Department of Economics, Faculty of Economics and Business, Universitas Gadjah Mada, Special Region of Yogyakarta, Indonesia

\section{*CORRESPONDENCE:}

akhmad.susamto@ugm.ac.id

THIS ARTICLE IS AVALILABLE IN:

http://journal.umy.ac.id/index.php/esp

DOI: 10.18196/jesp.v22i2.11918

\section{CITATION:}

Friantoro, D., \& Susamto, A.A. (2021). The Determinants of the Value of Mahr in Muslim Societies: Evidence from the Indonesian Family Life Surveys. Jurnal Ekonomi \& Studi Pembangunan, 22(2), 323338.

\section{ARTICLE HISTORY}

\section{Received:}

08 Jun 2021

Revised:

20 Sep 2021

Accepted:

31 Oct 2021

\begin{abstract}
This paper aims to analyze the factors that determine the value of mahr in Muslim societies. The analysis is based on an ordinary least squares (OLS) regression with pooled cross-section data from the last three waves of the Indonesian Family Life Surveys (IFLS). The main finding is that socioeconomic status in the forms of groom's ownership of assets and education level matters most for the value of mahr. This finding holds for regression with full sample as well as subsamples, i.e. couples whose groom is Javanese, couples whose groom is nonJavanese, couples whose bride is Javanese and couples whose bride is nonJavanese. Socioeconomic status in the form of bride's education level also matters for the value of mahr with some exceptions. The other finding is that perceived probability of divorce as represented by differences in the socioeconomic status of a marrying couple do not have a significant effect on the value of mahr. The effect of physical appearances in the form of bride's height is at best not robust and subject to the sample or subsample included. These findings can be useful as a reference to make marriage decisions in the future or to evaluate the ongoing practices for possible reforms.
\end{abstract}

Keywords: Mahr; Marriage; Muslim; IFLS

JEL Classification: J12; N30

\section{Introduction}

Mahr -the handing of money or other kind of properties from a groom to a bride- is a legal condition of marriage in Islam, at least as agreed by most Muslim scholars. There remain different views on whether a marriage without a mahr is valid, but it is clear that the mahr is obligatory based on the primary sources of Islam (the Quran and the Sunnah) (Maghniyyah, 1997; But \& Muhametov, 2013; Siddiqui, 1995; Wani, 2001).

Despite this imposition, there were no specific guidelines on how much the value of mahr should be. It is only mentioned that a proper value of mahr is one that is affordable and not burdensome. To cite the words of the Prophet Muhammad, "The best of mahr is the least one (or the most affordable one)" (as narrated by Abu Dawud and Al-Hakim, see e.g. Saheeh al-Jaami', 3279). 
In the absence of such specific guidelines, Muslim scholars have come with different opinions about the value of mahr. For example, interpreting one of the ayah in the Quran, An Nisa': 20, (Alu Syaikh et al., 2018) put an emphasis on the permissibility of awarding a big amount of mahr. Commenting on the same ayah in the Quran, (As-siba'i, 1999) states that a mahr should be given in a valuable form as it symbolizes the highness of marriage. Scholars of the Hanafi school set the minimum amount of mahr at 10 silver dirhams (equivalent to 33.6 grams of silver or 4.8 grams of gold), while those of the Maliki school limit the minimum value of mahr to 3 silver dirhams. To them, a mahr less than the minimum value is unacceptable, even if it was agreed upon. Scholars of the Shafii and Hambali schools do not see any strong arguments to limit the minimum value of mahr and opt to leave the decision to grooms and brides (Maghniyyah, 1997; But \& Muhametov, 2013).

In practice, the value of mahr has varied significantly across different individuals and societies (Afzal et al., 1973; Aini, 2014; Korson, 1968). History and regulation have, to some extent, played a role in the determination of the value of mahr (Abd Wakil \& Ahmad, 2017; Azahari \& Ali, 2015). However, other factors may have also been relevant. For example, it has been found that the average value of mahr is higher in urban areas than in rural areas (Habibi, 1997) and in high socioeconomic areas than in middle and low socioeconomic areas (Afzal et al., 1973; Korson, 1968).

Remarkably, despite the long historical practice of mahr in Muslim society, there is only limited number of studies examining the value of mahr and its determinants (Afzal et al., 1973; Aini, 2014; Habibi, 1997; Korson, 1968; Kurniawan, 2019). Most of these studies are descriptive (Habibi, 1997 and Kurniawan, 2019, are perhaps an exception). The majority of the works in the past focus on the Islamic rulings on mahr (Azzam et al., 2011; Danyal, 2015; Ghazali, 2008; Maghniyyah, 1997; Rahman, 1970; Ridha, 1975; Siddiqui, 1995; Syafqat, 1979). A number of works look at the legal rulings on mahr in certain countries (El Alami \& Hinchcliffe, 1996; Mehdi, 2001; Wani, 2001), while several others discuss mahr from sociocultural or sociopolitical contexts (e.g. Abd Wakil \& Ahmad, 2017; Azahari \& Ali, 2015; Ishak, 1983; Korson, 1968; Mehdi, 2001; Wynn, 2008; Yassari, 2013). Empirical analyses on mahr have been dominated by studies using anthropological methods to describe how mahr is practiced in a specific Muslim society (Moors, 1994; Nurcahyono, 2020; Sahay \& Sahay, 1996; Tugby, 1959).

It should be noted that the term mahr in Islamic context is different from another term that is often mistakenly used as its English translation, dowry. Mahr -sometimes also called mehr, mehir, mehrieh, mahriyeh, maskahwin or maskawin- is something that a bride is entitled to receive from her groom on marriage. Mahr serves as a form of gifts to express love and affection. It also serves as a form of savings that can be used for a bride's own benefit, to help build her family or to provide herself with some degree of economic security in the event of future marital dissolution due to her husband's death or divorce (Azahari \& Ali, 2015; Korson, 1968; Ridha, 1975; Singh, 2010). By contrast, dowry is money or other kind of properties that a bride and her family bring forth to the marriage. It is paid by a bride and her family to a groom and his family rather than the other way around. The term mahr is closer to the term dower in a sense that the direction of the payment is 


\section{Friantoro \& Susamto}

The Determinants of the Value of Mahr in Muslim Societies: ...

from a groom to a bride (Habibi, 1997). However, mahr is obligatory and needs to be specified at the time of marriages (regardless of whether the payment is made immediately or deferred), while dower is optional and not paid until the death of the husband. The term mahr is also different from bride price. The later refers to money or other kind of properties paid by a groom and his family to the parents of a bride upon marriage (Korson, 1968). Rather than the bride herself, it is her family that is entitled to receive the payment.

The current paper aims to analyze the factors that determine the value of mahr in the marriage of Muslims. The question to be answered in this paper is whether the socioeconomic status of a groom and a bride, differences in the socioeconomic status of a groom and a bride, and the physical appearances of a marrying couple have a significant effect on the value of mahr. This paper focuses particularly on the case of Muslims in Indonesia.

This paper extends the works by Habibi (1997) which focuses on the case of marriages in Iran and the work by Kurniawan (2020) which focuses only on the case of marriages in eastern Indonesia. Within the empirical literature of mahr in general, this paper complements the previous works examining the value of mahr (Afzal et al., 1973; Aini, 2014; Korson, 1968) or describing how mahr is practiced in a specific Muslim society (Moors, 1994; Nurcahyono, 2020; Sahay \& Sahay, 1996; Tugby, 1959).

Theoretically, the determination of the value of mahr can be explained using the economic theory of price. The value of mahr can be seen as a price affected by the demand from a bride and the offer (i.e. the supply) that comes from a groom.

To follow Habibi (1997), the value of mahr can also be seen as a result of a prenuptial negotiation between the parental families of a marrying couple. The key assumption is that the value of mahr demanded by a bride's family revolves around two concerns. First, perception of the risk of marital instability (i.e. the probability of divorce in the future). Since mahr is expected to provide a bride with some degree of economic security in the event of marital dissolution (Azahari \& Ali, 2015; Korson, 1968; Ridha, 1975; Singh, 2010), the higher the perceived risk of marital instability, the higher is the value of mahr demanded. From a different point of view, the higher the value of mahr, the less likely is the husband to unilaterally ask for a divorce in the future. Second, the view that mahr is a status symbol. Since mahr represents status, the higher the socioeconomic status of a bride, the higher is the value of mahr demanded.

Going by the above assumption, Habibi (1997) expects that from a bride's perspective, the value of mahr to be demanded is represented by the formula

$$
M^{d}=\left(\text { status }, P^{b}\right)
$$

where $M^{d}$ is the value of mahr to be demanded, status is the socioeconomic status of the bride and $P^{b}$ is the probability of future divorce as perceived by the bride's family. 


\section{Friantoro \& Susamto}

The Determinants of the Value of Mahr in Muslim Societies: ...

From a groom's perspective, it is also assumed by Habibi (1997) that the value of mahr revolves around the concerns on marital stability and the importance of mahr as a status symbol. In general, the higher the probability of divorce in the future, the lower is the value of mahr to be offered. The idea is that the groom wishes to reduce his material losses from future marital dissolution settlement. With respect to socioeconomic status, the groom considers both his own economic status and the socioeconomic status of his bride. For him and his family, the value of mahr to be offered is therefore represented by the formula

$$
M^{s}=M^{s}\left(\text { bride }^{\prime} \text { s status, groom's status, } P^{g}\right)
$$

where $M^{s}$ is the value of mahr to be offered, bride's status is the socioeconomic status of the bride, groom's status is the socioeconomic status of the groom, and $P^{g}$ is the probability of future divorce as perceived by the groom's family.

Theoretically, agreements on the value of mahr take place only if the value demanded by a bride's family is lower than the value offered by a groom's family. In other words, agreements on the value of mahr can occur only if

$$
M^{d}<M<M^{s}(3)
$$

where $M$ is the value of mahr agreed by the parental families of a groom and a bride.

Based on his model, Habibi (1997) comes to a hypothesis that the determinants of the value of mahr include three categories of socioeconomic variables, namely variables that affect the value of mahr demanded, variables that affect the value of mahr offered, and variables that affect the perceived probability of divorce in the future. Socioeconomic variables which affect the value of mahr demanded by a bride's family may include ownership of assets, income, employment status, education level, age and ethnicity. The same variables may also affect the value of mahr offered by the family of a groom.

The effects that ownership of assets and income have on the value of mahr are likely positive (Anderson, 2000; Murat, 2013). The effect of employment status is likely also positive (Dasog, 1998), similar with the effect of education level (Ashraf et al., 2018; Chowdhury, 2008; Dalmia \& Lawrence, 2005; Lowes \& Nunn, 2017). The higher the level of education of a groom or a bride, the higher is the value of mahr. The effect of age on the value of mahr is ambiguous (Chowdhury, 2008; Dalmia \& Lawrence, 2005). Likewise, the effect that ethnicity has on the value of mahr is ambiguous. Ethnicity can have a positive or negative relationship, depending on the details of each ethnic (Anderson, 2000; Chowdhury, 2008).

Empirically, it is not easy to measure the perceived probability of divorce in the future. Habibi (1997) uses kinship and geographic proximity between parental families as a proxy for such perceived probability. The idea is that the closer kinship and geographic proximity between a marrying couple's parental families, the lower is the risk of marital instability 
and the perceived probability of divorce in the future. In the current paper, rather than kinship and geographic proximity between parental families, it is differences in the socioeconomic status of a marrying couple that are used.

\section{Research Method}

To analyze the factors that determine the value of mahr in Muslim societies, this paper uses an ordinary least squares (OLS) regression with pooled cross-section data. The data are taken from the last three waves of the Indonesian Family Life Surveys (IFLS) that were conducted in the years 1999-2000, 2007-2008 and 2014-2015. These surveys as a whole represent around 83 percent of the Indonesian population and include more than 30 thousand individuals who live in 13 out of 34 provinces of the country (Strauss et al., 2016; Strauss et al., 2004, Strauss et al., 2009).

The unit of analysis in this paper is groom-and-bride couples. To be included in the sample, the couples must be Muslim (at least formally) and getting married for the first time in the year of surveys or in the year preceding the surveys. These criteria help reduce potential ambiguities due to differences in the contextual gist of mahr across different religions or across first, second, third and fourth marriages.

The variable to be explained in this paper refers to the natural logarithm of the value of mahr deflated by the consumer price index (CPI). It originates from the answers given by male respondents (i.e. grooms) to the question, "What was the value of the mahr of your current/most recent marriage at the time of the marriage?" in the IFLS' questionnaires.

In line with the theoretical exposition in the previous section, the main explanatory variables in this paper consist of the socioeconomic status of a groom and a bride and differences in the socioeconomic status of a groom and a bride. In addition, the explanatory variables in this paper include the physical appearances of a marrying couple, assuming that physical attractiveness matter for the value of mahr. The socioeconomic status of a groom and a bride include ownership of assets, income, employment status, level of education, age and ethnicity. Ownership of assets is defined as the total value of assets in rupiah, while income is defined as the total rupiah generated over the past year. Both asset ownership and income are deflated by the CPI and transformed into their natural logarithm form. Due to the prevalence of missing values, only asset ownership and income that belong to a groom are included in the analysis. Asset ownership and income that belong to a bride are excluded from the analysis. Employment status is represented by a dummy variable, taking the value 1 for employed and 0 otherwise. Level of education is defined as the number of years spent by a groom or a bride in formal education. Age refers to the age of a groom and a bride at the time of marriage. Ethnicity is represented by a dummy for Jawa, taking the value 1 if a groom or a bride is of Javanese ethnicity and 0 otherwise. Differences in the socioeconomic status of a groom and bride include education difference, age difference and ethnic difference. Education difference is measured as the years spent in formal education by a groom minus the years spent in formal education by a bride. Age difference is measured as the age of a groom minus the 


\section{Friantoro \& Susamto}

The Determinants of the Value of Mahr in Muslim Societies: ...

age of a bride. Ethnic difference is represented by a dummy variable, whose value equals 1 if a groom-and-bride couple is of different ethnic and 0 otherwise. Physical appearances include a measure of height and a dummy for body proportionality. The dummy for body proportionality is based on the concept of body mass index (BMI) -an index of weight-forheight introduced by the World Health Organization (WHO). The dummy for body proportionality is valued 1 if a groom or a bride is normal and 0 otherwise (i.e. underweight, overweight or obesity).

To take into account the effect of the years of surveys (and, thus, also the years of marriage), a few dummies for marriage years are included in the analysis. To avoid perfect collinearity, the dummy for year 1999 is left out and treated as a reference category.

The regression equation is provided by:

$$
\ln \left(Y_{i}\right)=\beta_{0}+\sum_{j=1}^{J} \beta^{j} X_{i}^{j}+\sum_{k=1}^{K} \beta^{k} Z_{i}^{k}+\sum_{q=1}^{Q} \beta^{q} P_{i}^{q}+\sum_{r=1}^{R} \beta^{r} D_{i}^{r}+\varepsilon_{i}
$$

where $\ln \left(Y_{i}\right)$ denotes the natural logarithm of CPI-deflated value of mahr, $X_{1}$ denotes a vector of the socioeconomic status of a groom and a bride, $Z_{i}$ denotes a vector of differences in the socioeconomic status of a groom and a bride, $P_{i}$ denotes a vector of the physical appearances of a groom and a bride and $Y_{i}$ denotes a vector of marriage year dummies. The alphabet $\varepsilon_{i}$ denotes error terms.

Estimations are carried out for regression with full sample and regression with subsamples. The later consist of regression with a subsample of couples whose groom belongs to Javanese ethnicity, regression with a subsample of couples whose groom belongs to non-Javanese ethnicity, regression with a subsample of couples whose bride belongs to Javanese ethnicity and regression with a subsample of couples whose bride belongs to non-Javanese ethnicity.

\section{Result and Discussion}

Table 1 reports the descriptive statistics. The (CPI deflated) value of mahr is very widely distributed, with an average of IDR 2,025,900 and a standard deviation of IDR 5,306,741. Preliminary evaluation indicates that the difference in the employment status of a groom and a bride is highly correlated with one or more of the other explanatory variables. This variable is therefore excluded from further analysis. Table 2 reports the variance inflation factors (VIF) and the tolerance values of the main explanatory variables after such exclusion. It can be seen that no VIF value exceeds 5.00 and no tolerance value is less than 0.10 , implying the absence of any collinearity issues. 
Friantoro \& Susamto

The Determinants of the Value of Mahr in Muslim Societies: ...

Table 1 Descriptive statistics

\begin{tabular}{lcccc} 
& Mean & Standard dev & Minimum & Maximum \\
\hline Mahr_Original value in rupiah & $\mathbf{( 1 )}$ & $\mathbf{( 2 )}$ & $\mathbf{( 3 )}$ & $\mathbf{( 4 )}$ \\
Mahr_Value in natural log & $2,025,900$ & $5,306,741$ & 11,880 & $72,050,000$ \\
Groom_Ownership of assets & 13.111 & 1.713 & 9.383 & 18.093 \\
Groom_Income & 15.140 & 1.515 & 9.952 & 20.294 \\
Groom_Employment status & 15.704 & 1.143 & 9.424 & 18.270 \\
Groom_Education level & 0.941 & 0.237 & 0.000 & 1.000 \\
Groom_Age & 10.421 & 3.407 & 0.000 & 18.000 \\
Groom_Javanese & 25.941 & 4.150 & 15.000 & 40.000 \\
Groom_Sundanese & 0.459 & 0.499 & 0.000 & 1.000 \\
Groom_Betawi & 0.125 & 0.331 & 0.000 & 1.000 \\
Groom_Body proportionality & 0.055 & 0.228 & 0.000 & 1.000 \\
Groom_Height & 1.018 & 0.645 & 0.000 & 3.000 \\
Bride_Employment status & 164.041 & 5.935 & 142.500 & 184.300 \\
Bride_Education level & 0.290 & 0.454 & 0.000 & 1.000 \\
Bride_Age & 10.703 & 3.309 & 0.000 & 18.000 \\
Bride_Javanese & 22.770 & 4.140 & 15.000 & 39.000 \\
Bride_Sundanese & 0.471 & 0.499 & 0.000 & 1.000 \\
Bride_Betawi & 0.126 & 0.333 & 0.000 & 1.000 \\
Bride_Body proportionality & 0.044 & 0.206 & 0.000 & 1.000 \\
Bride_Height & 1.110 & 0.691 & 0.000 & 3.000 \\
Difference in employment status & 151.686 & 5.324 & 125.300 & 170.500 \\
Difference in education level & 0.664 & 0.473 & 0.000 & 1.000 \\
Difference in age & 2.107 & 2.183 & 0.000 & 13.000 \\
Difference in ethnicity & 3.908 & 3.212 & 0.000 & 20.000 \\
\hline & 0.156 & 0.363 & 0.000 & 1.000 \\
\hline
\end{tabular}

Table 2 VIF and tolerance values

\begin{tabular}{lcc} 
& VIF values & Tolerance values \\
\hline & $(\mathbf{1})$ & (2) \\
\hline Groom_Ownership of assets & 1.330 & 0.754 \\
Groom_Income & 1.360 & 0.738 \\
Groom_Employment status & 1.030 & 0.968 \\
Groom_Education level & 1.720 & 0.583 \\
\hline Groom_Age & 4.180 & 0.239 \\
Groom_Javanese & 4.260 & 0.235 \\
Groom_Sundanese & 3.110 & 0.321 \\
Groom_Betawi & 2.450 & 0.407 \\
Groom_Body proportionality & 1.080 & 0.928 \\
Groom_Height & 1.150 & 0.868 \\
Bride_Employment status & 1.110 & 0.900 \\
Bride_Education level & 1.880 & 0.532 \\
Bride_Age & 3.160 & 0.316 \\
Bride_Javanese & 4.190 & 0.239 \\
Bride_Sundanese & 3.100 & 0.323 \\
Bride_Betawi & 2.370 & 0.422 \\
Bride_Body proportionality & 1.080 & 0.925 \\
Bride_Height & 1.070 & 0.935 \\
Difference in education level & 1.090 & 0.918 \\
Difference in employment status & & \\
a) & & \\
Difference in age & 3.070 & 0.326 \\
Difference in ethnicity & 1.100 & 0.911 \\
Note: a) Difference in employment status is excluded from the analysis due to possible collinearity. The \\
values reported are VIF and tolerance values computed after such exclusion. \\
\hline
\end{tabular}


Friantoro \& Susamto

The Determinants of the Value of Mahr in Muslim Societies: ...

\section{Basic Regression Results}

Table 3 reports the results from the OLS regression with full sample.

Table 3 Results from regression with full sample

\begin{tabular}{|c|c|c|c|c|}
\hline \multicolumn{5}{|c|}{ Full sample } \\
\hline & (1) & (2) & (3) & (4) \\
\hline \multirow[t]{2}{*}{ Groom_Ownership of assets } & $0.187^{* * *}$ & $0.183^{* * *}$ & $0.182 * * *$ & $0.178 * * *$ \\
\hline & $(0.040)$ & $(0.040)$ & $(0.041)$ & $(0.040)$ \\
\hline \multirow[t]{2}{*}{ Groom_Income } & -0.030 & -0.033 & -0.039 & -0.041 \\
\hline & $(0.055)$ & $(0.056)$ & $(0.055)$ & $(0.056)$ \\
\hline \multirow[t]{2}{*}{ Groom_Employment status } & -0.039 & -0.027 & -0.028 & -0.017 \\
\hline & $(0.239)$ & $(0.234)$ & $(0.240)$ & $(0.236)$ \\
\hline \multirow[t]{2}{*}{ Groom_Education level } & $0.090 * * *$ & $0.086 * * *$ & $0.089 * * *$ & $0.085 * * *$ \\
\hline & $(0.019)$ & $(0.020)$ & $(0.020)$ & $(0.020)$ \\
\hline \multirow[t]{2}{*}{ Groom_Age } & 0.003 & -0.013 & 0.000 & -0.017 \\
\hline & $(0.016)$ & $(0.025)$ & $(0.016)$ & $(0.025)$ \\
\hline \multirow[t]{2}{*}{ Groom_Javanese } & 0.128 & 0.140 & 0.113 & 0.123 \\
\hline & $(0.194)$ & $(0.198)$ & (0.193) & (0.198) \\
\hline \multirow[t]{2}{*}{ Groom_Sundanese } & $0.528^{* *}$ & $0.518^{* *}$ & $0.510^{* *}$ & $0.500 * *$ \\
\hline & $(0.220)$ & $(0.222)$ & $(0.221)$ & $(0.223)$ \\
\hline \multirow[t]{2}{*}{ Groom_Betawi } & $1.102 * * *$ & $1.035^{* * *}$ & $1.130 * * *$ & $1.067 * * *$ \\
\hline & $(0.280)$ & $(0.282)$ & $(0.281)$ & $(0.282)$ \\
\hline \multirow[t]{2}{*}{ Groom_Body proportionality } & 0.090 & 0.095 & 0.091 & 0.096 \\
\hline & $(0.082)$ & $(0.083)$ & $(0.082)$ & $(0.083)$ \\
\hline \multirow[t]{2}{*}{ Groom_Height } & -0.007 & -0.007 & -0.009 & -0.009 \\
\hline & (0.009) & (0.009) & (0.009) & (0.009) \\
\hline \multirow[t]{2}{*}{ Bride_Employment status } & 0.108 & 0.104 & 0.096 & 0.092 \\
\hline & $(0.114)$ & $(0.114)$ & $(0.114)$ & $(0.115)$ \\
\hline \multirow[t]{2}{*}{ Bride_Education level } & $0.060 * * *$ & $0.059 * * *$ & $0.057^{* * *}$ & $0.057^{* * *}$ \\
\hline & $(0.021)$ & $(0.022)$ & $(0.021)$ & $(0.022)$ \\
\hline \multirow[t]{2}{*}{ Bride_Age } & 0.006 & 0.020 & 0.008 & 0.022 \\
\hline & $(0.017)$ & $(0.023)$ & $(0.017)$ & $(0.023)$ \\
\hline \multirow[t]{2}{*}{ Bride_Javanese } & $-0.455^{* *}$ & $-0.460 * *$ & $-0.463 * *$ & $-0.468 * *$ \\
\hline & $(0.191)$ & $(0.195)$ & $(0.191)$ & $(0.195)$ \\
\hline \multirow[t]{2}{*}{ Bride_Sundanese } & -0.286 & -0.305 & -0.276 & -0.295 \\
\hline & $(0.228)$ & $(0.230)$ & $(0.230)$ & (0.231) \\
\hline \multirow[t]{2}{*}{ Bride_Betawi } & -0.177 & -0.138 & -0.227 & -0.191 \\
\hline & $(0.318)$ & $(0.314)$ & $(0.318)$ & $(0.315)$ \\
\hline \multirow[t]{2}{*}{ Bride_Body proportionality } & & & 0.064 & 0.060 \\
\hline & & & $(0.075)$ & $(0.075)$ \\
\hline \multirow[t]{2}{*}{ Bride_Height } & & & $0.023^{* *}$ & $0.023 * *$ \\
\hline & & & $(0.010)$ & $(0.010)$ \\
\hline \multirow[t]{2}{*}{ Difference in education level } & & -0.028 & & -0.029 \\
\hline & & $(0.024)$ & & $(0.024)$ \\
\hline \multirow[t]{2}{*}{ Difference in age } & & 0.024 & & 0.025 \\
\hline & & (0.029) & & $(0.028)$ \\
\hline \multirow[t]{2}{*}{ Difference in ethnicity } & & 0.183 & & 0.168 \\
\hline & & (0.139) & & (0.139) \\
\hline $\mathrm{N}$-observations & 925 & 925 & 925 & 925 \\
\hline R-squared & 0.217 & 0.221 & 0.223 & 0.226 \\
\hline
\end{tabular}


In column 1, the regression includes a constant, the socioeconomic status of a groom and a bride, and year of marriage dummies. In column 2, differences in the socioeconomic status of each groom-and-bride couple are added into the regression. In column 3, measures of physical appearances instead of differences in the socioeconomic status of a marrying couple are included in the regression. In column 4, the regression includes all of the explanatory variables together. Irrespective of the explanatory variables included, the coefficients of groom's ownership of assets and groom's education level are positive and significant at the 1 percent level. The coefficient of bride's education level is also positive and significant at the 1 percent level, signifying the importance of such variable for the value of mahr. The coefficients of groom's income, groom's and bride's employment status, and groom's and bride's age are not statistically significant.

The coefficients of the dummy for Sundanese groom and the dummy for Betawi groom are both positive and significant at least at the 5 percent level. By contrast, the coefficient of the dummy for Javanese bride is significantly negative at the 5 percent level.

The effects that differences in the socioeconomic status of a marrying couple have on the value of mahr are statistically negligible. None of the coefficients of difference in education level, difference in age and difference in ethnicity are significant.

Physical appearances in the form of bride's height have a positive and significant effect on the value of mahr. Physical appearances in the form of groom's height, groom's body proportionality dan bride's body proportionality do, however, not seem to be important for the value of mahr as their coefficients are not statistically significant.

Table 4 reports the results from the OLS regression with subsamples of couples whose groom belongs to Javanese ethnicity and couples whose groom belongs to non-Javanese ethnicity. In columns 1 and 3 , the regression includes a constant, the socioeconomic status of a groom and a bride, measures of physical appearances of a groom and a bride, and year of marriage dummies. In columns 2 and 4 , differences in the socioeconomic status of each groom-and-bride couple are added into the regression, allowing the natural logarithm of the value of mahr to be regressed on all of the explanatory variables together. The coefficients of groom's ownership of assets, groom's education level, and bride's education level are positive and significant at least at the 10 percent level. The coefficients of the dummy for Sundanese groom and the dummy for Betawi groom are also positive and significant in columns 3-4, implying the presence of a difference in the value of mahr paid by grooms across non-Javanese ethnicities. The coefficient of the dummy for Betawi bride is significantly positive in columns 1-2, but negative in columns 3-4. This infers that the effect of a bride's ethnicity on the value of mahr depends on the whether her groom is of Javanese or non-Javanese ethnicity. The coefficient of bride's height is positive and significant in the last columns, implying the importance of this variable for the value of mahr across the sample. 
Friantoro \& Susamto

The Determinants of the Value of Mahr in Muslim Societies: ...

Table 4 Results from regression with subsamples

\begin{tabular}{|c|c|c|c|c|}
\hline & \multicolumn{2}{|c|}{ Javanese groom } & \multicolumn{2}{|c|}{ Non-Javanese groom } \\
\hline & (1) & (2) & (3) & (4) \\
\hline \multirow{2}{*}{ Groom_Ownership of assets } & $0.147 * * *$ & $0.150 * * *$ & $0.209 * * *$ & $0.203 * * *$ \\
\hline & $(0.055)$ & $(0.056)$ & (0.059) & (0.059) \\
\hline \multirow[t]{2}{*}{ Groom_Income } & 0.010 & -0.004 & -0.110 & -0.100 \\
\hline & $(0.066)$ & $(0.068)$ & $(0.094)$ & $(0.094)$ \\
\hline \multirow[t]{2}{*}{ Groom_Employment status } & -0.066 & -0.067 & 0.026 & 0.056 \\
\hline & $(0.317)$ & $(0.313)$ & $(0.367)$ & $(0.348)$ \\
\hline \multirow[t]{2}{*}{ Groom_Education level } & $0.084^{* * *}$ & $0.075^{* * *}$ & $0.089 * * *$ & $0.093^{* * *}$ \\
\hline & $(0.026)$ & $(0.028)$ & $(0.029)$ & $(0.029)$ \\
\hline \multirow[t]{2}{*}{ Groom_Age } & 0.020 & $0.052^{*}$ & -0.025 & $-0.115^{* * *}$ \\
\hline & $(0.021)$ & $(0.028)$ & $(0.024)$ & $(0.039)$ \\
\hline \multirow[t]{2}{*}{ Groom_Sundanese } & & & $0.661^{* * *}$ & $0.692 * * *$ \\
\hline & & & $(0.235)$ & $(0.236)$ \\
\hline \multirow[t]{2}{*}{ Groom_Betawi } & & & $1.455^{* * *}$ & $1.488 * * *$ \\
\hline & & & $(0.291)$ & $(0.296)$ \\
\hline \multirow[t]{2}{*}{ Groom_Body proportionality } & -0.092 & -0.099 & $0.252^{* *}$ & $0.246 * *$ \\
\hline & (0.117) & $(0.118)$ & $(0.116)$ & $(0.115)$ \\
\hline \multirow[t]{2}{*}{ Groom_Height } & -0.004 & -0.004 & -0.014 & -0.017 \\
\hline & $(0.012)$ & $(0.012)$ & $(0.013)$ & $(0.013)$ \\
\hline \multirow[t]{2}{*}{ Bride_Employment status } & 0.234 & 0.214 & -0.019 & -0.031 \\
\hline & $(0.152)$ & $(0.150)$ & $(0.175)$ & $(0.176)$ \\
\hline \multirow[t]{2}{*}{ Bride_Education level } & $0.054^{*}$ & $0.050^{*}$ & $0.071^{* *}$ & $0.085^{* *}$ \\
\hline & $(0.028)$ & $(0.029)$ & $(0.031)$ & $(0.033)$ \\
\hline \multirow[t]{2}{*}{ Bride_Age } & -0.007 & -0.025 & 0.023 & $0.089 * *$ \\
\hline & $(0.020)$ & $(0.023)$ & $(0.027)$ & $(0.035)$ \\
\hline \multirow[t]{2}{*}{ Bride_Javanese } & -0.118 & -0.113 & $-0.617^{* *}$ & $-0.612^{* *}$ \\
\hline & $(0.297)$ & $(0.297)$ & $(0.251)$ & $(0.256)$ \\
\hline \multirow[t]{2}{*}{ Bride_Sundanese } & 0.042 & -0.008 & $-0.419^{*}$ & $-0.425^{*}$ \\
\hline & $(0.651)$ & $(0.642)$ & $(0.249)$ & $(0.249)$ \\
\hline \multirow[t]{2}{*}{ Bride_Betawi } & $1.704^{* * *}$ & $1.700 * * *$ & $-0.615^{*}$ & $-0.657^{*}$ \\
\hline & $(0.350)$ & $(0.348)$ & $(0.348)$ & $(0.350)$ \\
\hline \multirow[t]{2}{*}{ Bride_Body proportionality } & 0.106 & 0.111 & 0.010 & 0.015 \\
\hline & $(0.095)$ & $(0.096)$ & $(0.113)$ & $(0.111)$ \\
\hline \multirow[t]{2}{*}{ Bride_Height } & -0.008 & -0.007 & $0.042 * * *$ & $0.043^{* * *}$ \\
\hline & $(0.014)$ & $(0.014)$ & $(0.014)$ & $(0.014)$ \\
\hline \multirow[t]{2}{*}{ Difference in education level } & & $-0.057^{*}$ & & 0.000 \\
\hline & & $(0.033)$ & & $(0.037)$ \\
\hline \multirow[t]{2}{*}{ Difference in age } & & -0.045 & & $0.119 * * *$ \\
\hline & & $(0.031)$ & & $(0.043)$ \\
\hline $\mathrm{N}$-observations & 425 & 425 & 500 & 500 \\
\hline R-squared & 0.209 & 0.218 & 0.244 & 0.256 \\
\hline
\end{tabular}

Table 5 reports the results from the OLS regression with subsamples of couples whose bride is Javanese and couples whose bride is non-Javanese. In columns 1 and 3, again, the regression includes a constant, the socioeconomic status of a groom and a bride, the physical appearances of a groom and a bride, and year of marriage dummies. In columns 2 and 4, the differences in the socioeconomic status of a groom and a bride are also included in the regression. The coefficients of groom's ownership of assets and groom's education level are again positive and significant. The coefficient of bride's education level 


\section{Friantoro \& Susamto}

The Determinants of the Value of Mahr in Muslim Societies: ...

is positive, but statistically significant only in columns $3-4$. Holding other variables constant, bride's education level matters for the value of mahr only when the bride is of non-Javanese ethnicity. The coefficient of the dummy for Betawi groom is significantly positive. The coefficient of bride's height is again positive and significant in columns 3-4, implying the importance of this variable across couples with a non-Javanese bride.

Table 5 Results from regression with subsamples

\begin{tabular}{|c|c|c|c|c|}
\hline & \multicolumn{2}{|c|}{ Javanese bride } & \multicolumn{2}{|c|}{ Non-Javanese bride } \\
\hline & (1) & (2) & (3) & (4) \\
\hline \multirow[t]{2}{*}{ Groom_Ownership of assets } & $0.111^{* *}$ & $0.114 * *$ & $0.245^{* * *}$ & $0.236 * * *$ \\
\hline & $(0.053)$ & $(0.053)$ & $(0.060)$ & $(0.060)$ \\
\hline \multirow[t]{2}{*}{ Groom_Income } & -0.001 & -0.014 & -0.100 & -0.086 \\
\hline & $(0.064)$ & $(0.066)$ & $(0.096)$ & $(0.096)$ \\
\hline \multirow[t]{2}{*}{ Groom_Employment status } & -0.079 & -0.065 & 0.090 & 0.142 \\
\hline & $(0.295)$ & $(0.290)$ & $(0.424)$ & $(0.394)$ \\
\hline \multirow[t]{2}{*}{ Groom_Education level } & $0.095^{* * *}$ & $0.085 * * *$ & $0.082 * * *$ & $0.087 * * *$ \\
\hline & $(0.026)$ & $(0.027)$ & $(0.029)$ & $(0.029)$ \\
\hline \multirow[t]{2}{*}{ Groom_Age } & 0.015 & $0.046^{*}$ & -0.014 & $-0.107 * *$ \\
\hline & $(0.020)$ & $(0.027)$ & $(0.024)$ & $(0.042)$ \\
\hline \multirow[t]{2}{*}{ Groom_Javanese } & 0.324 & 0.340 & -0.005 & -0.005 \\
\hline & $(0.324)$ & $(0.320)$ & $(0.280)$ & $(0.282)$ \\
\hline \multirow[t]{2}{*}{ Groom_Sundanese } & $0.724^{*}$ & $0.699 *$ & 0.430 & 0.440 \\
\hline & $(0.423)$ & $(0.420)$ & $(0.269)$ & $(0.272)$ \\
\hline \multirow[t]{2}{*}{ Groom_Betawi } & $1.642^{* * *}$ & $1.648 * * *$ & $1.007 * * *$ & $0.989 * * *$ \\
\hline & $(0.625)$ & $(0.601)$ & $(0.293)$ & $(0.296)$ \\
\hline \multirow[t]{2}{*}{ Groom_Body proportionality } & 0.039 & 0.028 & 0.138 & 0.131 \\
\hline & $(0.118)$ & (0.119) & $(0.116)$ & $(0.115)$ \\
\hline \multirow[t]{2}{*}{ Groom_Height } & -0.003 & -0.001 & -0.013 & -0.015 \\
\hline & $(0.012)$ & $(0.011)$ & $(0.013)$ & $(0.013)$ \\
\hline \multirow[t]{2}{*}{ Bride_Employment status } & 0.097 & 0.071 & 0.047 & 0.036 \\
\hline & $(0.145)$ & $(0.144)$ & $(0.181)$ & $(0.181)$ \\
\hline \multirow[t]{2}{*}{ Bride_Education level } & 0.032 & 0.026 & $0.091 * * *$ & $0.105 * * *$ \\
\hline & $(0.027)$ & $(0.029)$ & $(0.032)$ & $(0.034)$ \\
\hline \multirow[t]{2}{*}{ Bride_Age } & 0.010 & -0.007 & 0.003 & $0.073^{*}$ \\
\hline & $(0.020)$ & $(0.022)$ & $(0.028)$ & $(0.038)$ \\
\hline \multirow[t]{2}{*}{ Bride_Sundanese } & & & -0.181 & -0.163 \\
\hline & & & $(0.261)$ & $(0.264)$ \\
\hline \multirow[t]{2}{*}{ Bride_Betawi } & & & -0.112 & -0.109 \\
\hline & & & $(0.323)$ & $(0.324)$ \\
\hline \multirow[t]{2}{*}{ Bride_Body proportionality } & 0.123 & 0.133 & 0.006 & 0.013 \\
\hline & $(0.096)$ & $(0.097)$ & $(0.116)$ & (0.115) \\
\hline \multirow[t]{2}{*}{ Bride_Height } & 0.001 & 0.001 & $0.037 * * *$ & $0.039 * * *$ \\
\hline & $(0.013)$ & $(0.013)$ & $(0.014)$ & $(0.014)$ \\
\hline \multirow[t]{2}{*}{ Difference in education level } & & $-0.068 * *$ & & 0.004 \\
\hline & & $(0.033)$ & & $(0.037)$ \\
\hline \multirow[t]{2}{*}{ Difference in age } & & -0.043 & & $0.125 * * *$ \\
\hline & & $(0.030)$ & & $(0.046)$ \\
\hline $\mathrm{N}$-observations & 436 & 436 & 489 & 489 \\
\hline R-squared & 0.193 & 0.204 & 0.250 & 0.263 \\
\hline \multicolumn{5}{|c|}{$\begin{array}{l}\text { Note: The explained variable is the natural logarithm of the value of mahr. Each regression includes a } \\
\text { constant and year of marriage dummies. The values in parentheses are heteroskedasticity-robust } \\
\text { standard errors. } *, * * \text { and } * * * \text { indicates significance at the } 10,5 \text { or } 1 \text { percent level. }\end{array}$} \\
\hline
\end{tabular}




\section{Friantoro \& Susamto}

The Determinants of the Value of Mahr in Muslim Societies: ...

\section{Results from Robustness Tests}

The above estimations include groom's income, groom's employment status and bride's employment status whose coefficients never turn out to be statistically significant. This may cause model overfitting and mislead the results. To deal with such concern, estimations in Table 3 are repeated without the aforementioned three variables.

Table 6 Results from robustness tests

\begin{tabular}{|c|c|c|c|c|}
\hline & Full sample & & & \\
\hline & (1) & (2) & (3) & (4) \\
\hline \multirow[t]{2}{*}{ Groom_Ownership of assets } & $0.183^{* * *}$ & $0.176 * * *$ & $0.179 * * *$ & $0.173^{* * *}$ \\
\hline & $(0.040)$ & $(0.040)$ & $(0.040)$ & $(0.040)$ \\
\hline \multirow[t]{2}{*}{ Groom_Education level } & $0.090 * * *$ & $0.089 * * *$ & $0.086 * * *$ & $0.085 * * *$ \\
\hline & $(0.019)$ & $(0.020)$ & $(0.020)$ & $(0.020)$ \\
\hline \multirow[t]{2}{*}{ Groom_Age } & 0.002 & -0.001 & -0.015 & -0.019 \\
\hline & $(0.016)$ & $(0.016)$ & $(0.025)$ & $(0.025)$ \\
\hline \multirow[t]{2}{*}{ Groom_Javanese } & 0.134 & 0.119 & 0.145 & 0.128 \\
\hline & $(0.193)$ & $(0.192)$ & $(0.197)$ & $(0.196)$ \\
\hline \multirow[t]{2}{*}{ Groom_Sundanese } & $0.531 * *$ & $0.510 * *$ & $0.520^{* *}$ & $0.500 * *$ \\
\hline & $(0.217)$ & $(0.217)$ & $(0.220)$ & $(0.220)$ \\
\hline \multirow[t]{2}{*}{ Groom_Betawi } & $1.101^{* * *}$ & $1.123 * * *$ & $1.033 * * *$ & $1.060 * * *$ \\
\hline & $(0.278)$ & $(0.278)$ & $(0.280)$ & $(0.280)$ \\
\hline \multirow[t]{2}{*}{ Groom_Body proportionality } & 0.086 & 0.086 & 0.090 & 0.090 \\
\hline & $(0.081)$ & $(0.080)$ & $(0.081)$ & $(0.081)$ \\
\hline \multirow[t]{2}{*}{ Groom_Height } & -0.008 & -0.010 & -0.007 & -0.009 \\
\hline & $(0.009)$ & (0.009) & $(0.009)$ & $(0.009)$ \\
\hline \multirow[t]{2}{*}{ Bride_Education level } & $0.060 * * *$ & $0.057 * * *$ & $0.059 * * *$ & $0.057 * * *$ \\
\hline & $(0.021)$ & $(0.021)$ & $(0.021)$ & $(0.022)$ \\
\hline \multirow[t]{2}{*}{ Bride_Age } & 0.008 & 0.010 & 0.022 & 0.024 \\
\hline & $(0.017)$ & $(0.017)$ & $(0.023)$ & $(0.023)$ \\
\hline \multirow[t]{2}{*}{ Bride_Javanese } & $-0.453 * *$ & $-0.461 * *$ & $-0.458 * *$ & $-0.466 * *$ \\
\hline & $(0.190)$ & $(0.190)$ & $(0.194)$ & $(0.193)$ \\
\hline \multirow[t]{2}{*}{ Bride_Sundanese } & -0.286 & -0.276 & -0.305 & -0.295 \\
\hline & $(0.226)$ & $(0.227)$ & $(0.228)$ & $(0.228)$ \\
\hline \multirow[t]{2}{*}{ Bride_Betawi } & -0.193 & -0.244 & -0.156 & -0.208 \\
\hline & $(0.314)$ & $(0.314)$ & $(0.310)$ & $(0.311)$ \\
\hline \multirow[t]{2}{*}{ Bride_Body proportionality } & & 0.064 & & 0.060 \\
\hline & & $(0.074)$ & & $(0.075)$ \\
\hline \multirow[t]{2}{*}{ Bride_Height } & & $0.023 * *$ & & $0.023 * *$ \\
\hline & & $(0.010)$ & & $(0.010)$ \\
\hline \multirow[t]{2}{*}{ Difference in education level } & & & -0.028 & -0.029 \\
\hline & & & $(0.024)$ & $(0.024)$ \\
\hline \multirow[t]{2}{*}{ Difference in age } & & & 0.025 & 0.026 \\
\hline & & & $(0.029)$ & $(0.028)$ \\
\hline \multirow[t]{2}{*}{ Difference in ethnicity } & & & 0.180 & 0.163 \\
\hline & & & $(0.137)$ & $(0.136)$ \\
\hline $\mathrm{N}$-observations & 925 & 925 & 925 & 925 \\
\hline R-squared & 0.216 & 0.222 & 0.220 & 0.225 \\
\hline
\end{tabular}




\section{Friantoro \& Susamto}

The Determinants of the Value of Mahr in Muslim Societies: ...

The results are reported in Table 6. The coefficients of groom's ownership of assets, groom's education level, and bride's education level remain statistically significant. The coefficients of the dummy for Sundanese groom, the dummy for Betawi groom and the dummy for Javanese bride also remain significant. The coefficient of bride's height does not qualitatively change and remain significantly positive at the 5 percent level.

Further tests suggest that the results in Table 3-5 are robust. Due to space restrictions, the details of these tests are not presented here, but available from the authors upon request.

\section{Further Discussions}

The fact that groom's ownership of assets, groom's level of education and bride's level of education have a significant effect on the value of mahr supports the hypothesis that the socioeconomic status of a groom matters (Habibi, 1997). This is also in line with previous findings that ownership of assets and level of education affect the value of dowry in Pakistan and India (Anderson, 2000; Dalmia \& Lawrence, 2005; Murat, 2013). The fact that groom's income, groom's and bride's employment status, groom's and bride's age, and groom's and bride's ethnicity do not have a robust significant effect on the value mahr, however, qualifies that the relationship between socioeconomic status and the value of mahr is not the same for all forms of socioeconomic status.

In contrast to the theoretical prediction (Habibi, 1997), perceived probability of divorce as represented by differences in in education level, age and ethnicity of a marrying couple- does not have a significant effect on the value of mahr. Perhaps, it is due to overoptimism among parental families of the marrying couple regarding the stability of their marriage, making the perceived probability of divorce slender.

Finally, the facts that body proportionality does not have a significant effect on the value of mahr and that the effect of bride's height is not robust to sample or subsample composition lend no support to the hypothesis that physical appearances matter. This is consistent with previous finding (Habibi, 1997) that body proportionality and height are not empirically important for the value of mahr.

\section{Conclusion}

This paper analyzes the factors that determine the value of mahr in the marriage of Muslims. It uses ordinary least squares (OLS) regressions covering a sample of 951 groomand-bride couples from the last three waves of the Indonesian Family Life Surveys (IFLS).

The main finding is that socioeconomic status in the forms of groom's ownership of assets and groom's education level matter most for the value of mahr. This holds for all regression scenarios, i.e. regressions with full sample, with a subsample of couples whose groom belongs to Javanese ethnicity, with a subsample of couples whose groom belongs to non-Javanese ethnicity, with a subsample of couples whose bride belongs to Javanese 


\section{Friantoro \& Susamto}

The Determinants of the Value of Mahr in Muslim Societies: ...

ethnicity and with a subsample of couples whose bride belongs to non-Javanese ethnicity. Socioeconomic status in the form of bride's education level matters, with exceptions for regression that includes couples whose bride is Javanese. Socioeconomic status in the forms of groom's income, groom's employment status and bride's employment status do not have a significant effect on the value mahr. Perceived risk of divorce as represented by differences in the socioeconomic status of a marrying couple do not have a significant effect on the value of mahr. The effect of physical appearances in the form of body proportionality do not have a significant effect on the value of mahr, while the effect of physical appearances in the form of bride's height is at best not robust and subject to the sample or subsample included.

The finding in this paper can be useful as a reference to help future grooms and brides to make decisions related to their marriage, particularly decisions on the value of mahr to offer or to demand. The finding in this paper can also be useful to help Muslim societies in general to evaluate the ongoing practices and anticipate possible reforms.

While best effort has been made to ensure the validity of the current research, further examination is needed. Perhaps by expanding the number and diversity of marrying couples in the sample, improving the measurement of the value of mahr, or using better proxies for perceived probability of divorce.

\section{References}

Abd Wakil, M. N., \& Ahmad, C. M. (2017). The historical impact on the valuation of dowry (Mahr) Rate: pre and post-colonial eras in Johor. Ulum Islamiyyah, 22, 11-20. https://doi.org/10.33102/uij.vol22no0.4

Afzal, M., Bean, L. L., \& Husain, I. (1973). Muslim marriages: age, mehr, and social status. The Pakistan Development Review, 12(1), 48-61. https://doi.org/10.30541/v12i1pp.48-61

Aini, N. (2014). Tradisi mahar di ranah lokalitas umat islam: mahar dan struktur sosial di masyarakat muslim indonesia. AHKAM : Jurnal Ilmu Syariah, 14(1). Retrieved from http://journal.uinjkt.ac.id/index.php/ahkam/article/view/1239

Alu Syaikh, A.M., Ghoffar, A., \& Abu Ihsan, A. (2018). Terjemaban kitab Lubabut tafsir min Ibni Katsir. Jakarta: Pustaka Imam Asy-Syafi'i.

Anderson, K. S. (2000). The economics of dowry payments in Pakistan. Center for Economic Research. Retrieved from https://pure.uvt.nl/ws/portalfiles/portal/536650/82.pdf

Ashraf, N., Bau, N., Nunn, N., \& Voena, A. (2018). Bride price and female education. National Bureau of Economic Research. https://doi.org/10.3386/w22417

As-siba'i, M. (1999). Al Mar ah baina al-figh wa al-ganun. Beirut: Muassasah

Azahari, R., \& Ali, H. M. (2015). Mahr as a form of economic security: a preliminary study. Arab Law Quarterly, 29(3), 296-305. https://doi.org/10.1163/15730255-12341300

Azzam, A.A.M., Hawwas, A.W.S., Khon, A.M. (2011). Fiqh munakahat: khitbah, nikah, dan talak. Jakarta: Amzah.

But, L-O., \& Muhametov, A-R. (2013). Love and sex in Islam. Murad Sayfuddin.

Chowdhury, A.R. (2008). Money and marriage: a fresh look at marriage transactions in rural India. Dissertation. Brown University. 


\section{Friantoro \& Susamto}

The Determinants of the Value of Mahr in Muslim Societies: ...

Dalmia, S., \& Lawrence, P.G. (2005). The institution of dowry in India: why it continues to prevail. The Journal of Developing Areas, 38(2), 71-93. Retrieved from http://www.jstor.org/stable/4192976

Danyal, K. (2015). Muslim law of marriage dower, divorce and maintenance. Regal Publications. Dasog, S.B. (1998). Dowry system in rural India. Karnatak University.

El Alami, D.S., \& Hinchcliffe, D. (1996). Islamic marriage and divorce laws of the Arab world. London: Published for CIMEL SOAS by Kluwer Law International.

Ghazali, A.R. (2008). Fiqh Munakahat. 3rd Ed. Jakarta: Kencana Media Group.

Habibi, N. (1997). An economic analysis of the prenuptial agreement ("mahrieh") in contemporary Iran. Economic Development and Cultural Change, 45(2), 281-293. https://doi.org/10.1086/452274

Ishak, O. (1983). Maskahwin dalam perundangan Islam dan pelaksanaannya di Semenanjung Malaysia. Jurnal Hukum, 3(1), 20-29.

Korson, J. H. (1968). The roles of dower and dowry as indicators of social change in Pakistan. Journal of Marriage and Family, 30(4), 696-707. https://doi.org/10.2307/349519

Kurniawan, R. (2020). Determinants of the dowry: finding from IFLS east. Jurnal Dinamika Ekonomi Pembangunan, 2(2), 71-79. https://doi.org/10.14710/jdep.2.2.71-79

Lowes, S., \& Nunn, N. (2018). Bride price and the wellbeing of women. Oxford: Oxford University Press.

Maghniyyah, M. J. (1997). Marriage, according to the five schools of Islamic law. Tehran: Islamic Culture and Relations Organization.

Mehdi, R. (2001). Gender and property law in Pakistan. Copenhagen: DJØF Publishing.

Moors, A. (1994). Women and dower property in twentieth-century Palestine: the case of Jabal Nablus. Islamic Law and Society, 1(3), 301-331. Retrieved from https://www.jstor.org/stable/3399234

Murat, J. (2013). The bridal income and education effects on the dowry a case study in Rural Karnataka, India. Lunds Universitet.

Nurcahyono, M.L. (2020). Perempuan dan hak-hak atas harta mahar, fungsi, dan persepsi masyarakat di Indonesia. Research Report IAIN Jember.

Rahman, T. (1970). Law of dower in Islam. All Pakistan Legal Decisions.

Ridha, M.R. (1975). Ifuqüq An-Nisa’ß l-Isläm. Beirut: Maktab al-Islàmï.

Sahay, R., \& Sahay, R. (1996). Dowry and dower in muslim marriage : a study among muslim Telis of Delhi. Indian Anthropologist, 26(1), 47-52. Retrieved from http://www.jstor.org/stable/41919792

Siddiqui, M. (1995). Mahr: legal obligation or rightful demand? Journal of Islamic Studies, 6(1), 14-24. Retrieved from http://www.jstor.org/stable/26195542

Singh, R. K. (2010). Law of dower (Mahr) in India. Journal of Islamic Law and Culture, 12(1), 58-73. https://doi.org/10.1080/1528817x.2010.528594

Strauss, J., Beegle, K., Sikoki, B., Dwiyanto, A., Herawati, Y., \& Witoelar, F. (2004). The third wave of the Indonesia Family Life Survey (IFLS3): Overview and field report.

Strauss, J., Witoelar, F., \& Sikoki, B. (2016). The Fifth Wave of the Indonesia Family Life Survey: Overview and Field Report.

Strauss, J., Witoelar, F., Sikoki, B., \& Wattie, A. M. (2009). The fourth wave of the Indonesian family life survey (IFLS4): overview and field report.

Syafqat, M. (1979). The muslin marriage, dower \& divorce. Lahore: Law Publishing Company.

Tugby, D. J. (1959). The social function of mahr in upper Mandailing, Sumatra. American Anthropologist, 61(4), 631-640. Retrieved from http://www.jstor.org/stable/667151 


\section{Friantoro \& Susamto}

The Determinants of the Value of Mahr in Muslim Societies: ...

Wani, M. A. (2001). Muslim women's right to "mahr": an appraisal of the statutory laws in Muslim countries. Journal of the Indian Law Institute, 43(3), 388-409. Retrieved from http://www.jstor.org/stable/43951783

Wynn, L. (2008). Marriage contracts and women's rights in Saudi Arabia: mahr, shurūt, and knowledge distribution. In A. Quraishi, \& F. E. Vogel (Eds.), The Islamic marriage contract: case studies in Islamic family law (pp. 200-214). (Harvard series in Islamic law). Islamic Legal Studies Program, Harvard Law School.

Yassari, N. (2013). Understanding and use of Islamic family law rules in German courts: the example of the mahr. In Applying sharia in the west-facts, fears and the future of Islamic rules on family relations in the $W$ est, Leiden University Press. 